\title{
Scrutinizing the Appropriateness of the Intermediate ILI English Series in the EFL Context of Iran
}

\author{
Amir Reza Asiyaban \\ Department of Foreign Languages, College of Humanities, Shiraz Branch, Islamic Azad University, Shiraz, Iran \\ Mostafa Zamanian \\ Department of Foreign Languages, College of Humanities, Shiraz Branch, Islamic Azad University, Shiraz, Iran
}

\begin{abstract}
Textbook evaluation has been a matter of interest in almost every EFL/ESL context. Since some aspects of the quality of language learning and teaching stem from the instructor's textbook adaptation and use and since different EFL/ESL textbooks target at touching different aspects of pupils' needs, carrying out an assessment of a particular textbook before its adoption and adaptation is of paramount importance. Accordingly, scrutinizing the weaknesses and strengths of the textbooks that are currently being taught in the most popular and the biggest institute of Iran seems to be inevitable. Hence, the aim of this study is to evaluate the Intermediate ILI (Iran Language Institute) English Series. To this end, eighty highly experienced male and female teachers from different branches in different cities of Iran were called for cooperation. The teachers ranged from BA holders to $\mathrm{PhD}$ candidates. In order to obtain the intended data, a forty item questionnaire developed by David R.A Litz (2000) was given to every instructor. Analyzing the data was done by running Independent samples t-test and basic statistics in SPSS 16 package for windows. The results show that although the series favor some strong points, the majority of the sections of the textbooks suffer a few number of pitfalls. Moreover, the overall evaluation of the series manifests the average level of satisfaction in every component on the part of the teachers. Also, the ideas of male and female instructors were different in "Conclusion", "Subject and Content" and "Language Type" categories.
\end{abstract}

Index Terms-textbook evaluation, EFL context, ESL context, pragmatic competence, communicative competence, linguistic competence

\section{INTRODUCTION}

The industry of textbook publication has been mainly the result of the global status of English in the world. A successful ELT course book can sell over a hundred thousand copies a year (Littlejohn, 1992). Textbooks play a crucial role in language teaching and learning realm and they are looked upon as an indispensable vehicle for foreign language learning. As noted by Cotazzi and Jin (1999), textbooks serve many roles in an EFL classroom, namely teacher, map, resource, trainer, authority, and ideology. Gray (2002) holds that ELT publishers present a vision of the world in the texts they produce, and despite being designed explicitly for the teaching of the language, they are carriers of cultural messages. That is why the authors of different textbooks should identify the elements that they believe are essential to a good textbook, and their information should be compiled into their projects. In other words, textbook designers should try to scrutinize learners' and instructors' needs before commencing their job on designing satisfactory and appropriate materials for the students and teachers.

A question that may be raised here is that what if a teacher does not intend to use a textbook in carrying out their profession? It should be noted that the necessity of using textbooks depends on some factors such as teacher's teaching style, resources available to them, and accepted standards of teaching wherever they may be used. Whatever instructors decide in terms of either using a textbook or not, they should bear in mind that no textbook is perfect and therefore, they should have the opinion of assigning supplementary materials based on their specific needs in their specific teaching situations.

Since textbooks markets abound with various appealing materials published by diverse companies, it is all but hard to choose one over the other. So, textbook evaluation is indispensible owing to this profusion. Ellis (1997a) also underscores the need for course book evaluation. Correspondingly, diverse textbook evaluations have been carried out by researchers through checklists and questionnaires application. Thus, scrutinizing the appropriateness of different textbooks seems to be of paramount importance so as to make the exploitation and selection of the most contextually appropriate, advantageous and prolific materials vivid. Cunningsworth (1995) and Ellis (1997b) believe that textbook evaluation helps teachers move beyond impressionistic assessments and helps them to get useful, accurate, systematic, and contextual insights into the overall nature of textbook material. In much the same way, quality textbooks assist learners in acquiring the concepts, skills and different components of language as well as widening their knowledge. 
Hence, textbook evaluation is necessary to maintain the quality of the textbooks and to ensure that they function as pupils' main sources of learning suitably.

In the similar fashion, the present paper is an attempt to evaluate one of the series being taught in the nationwide and the most popular institute of Iran, namely Iran Language Institute. To this end, the Intermediate ILI (Iran Language Institute) English Series will be the target of evaluation based on the opinions of the professional instructors in many cities in Iran. This study also aims to elucidate the appropriateness and usefulness of the above-mentioned series in terms of meeting students' needs in general and getting a good feedback on the series' approach, instructional philosophy, method and technique which suits the learners and their needs in particular.

\section{REVIEW OF THE RELATED LITERATURE}

\section{A. The Importance of Textbooks in EFL Contexts}

A textbook can be referred to as a published book especially designed to help language learners to improve their linguistic ad communicative abilities (Sheldon 1987). In addition to being a learning instrument, textbooks are also used as a supporting teaching instrument (O’Neil 1982, Ur1996). They are "designed to give cohesion to the language teaching and learning process by providing direction, support and specific language-based activities aimed at offering classroom practice for students" (Mares 2003) and foster effective and quick learning of the language (Cunningsworth 1995). Accordingly, Sohail (2011) maintains that textbooks are inseparable parts of teaching due to the following reasons:

- To help the pupil,

- To help the pupil,

- To help in self-teaching,

- To give the minimum essential Knowledge at one place,

- To provide logical and comprehensive material,

- To ensure uniformity of good standard,

- To provide both confirmation and sustenance,

- To provide a base from which both the teacher and the pupil may start and continue to work.

\section{B. The Need for Textbook Evaluation}

A number of studies have suggested that most current global, local ELT textbooks are developed for commercial purposes but are not based on principles of language acquisitions and development recommended by scholars and educators (Tomlinson, 2010). Financial success has become the primary goal of textbook publishing. Instead of contributing positively to student's development in the acquisition of language, many textbooks are in fact leading to learner's failure in acquiring the language and in the worst case, contain serious pedagogical flaws and practical shortcomings (Litz 2000).

According to Tomlinson (2008), the cause of language failure is twofold. The first one is germane to the need of commercial success which is reflected in the textbook moulding based on the liking of teachers, parents and administrators with a heavy focus on teaching of linguistic items instead of creating opportunities for students to acquire the language. The second cause of failure is that instead of focusing on how learners could actually benefit from using the textbook, textbook writers relied on their intuition and produce materials that they think would work best for their intended users. In other words, they are biased towards perceived rather than actual needs of learners.

Hence, choosing the right textbook is becoming more and more important at all levels of ELT. With the effort from textbook writers, ELT researchers and classroom teachers, textbook evaluation and selection have evolved into systematic action. Although most classroom teachers will not be involved in the production of textbooks, all teachers have the responsibility for textbook evaluation, selection and adaption.

In the light of the above, it is very important for us to conduct EFL textbook evaluation so as to ensure EFL textbooks can effectively facilitate the attainment of our teaching objectives (Mukundan 2007).

\section{A Review of Textbook Evaluation}

There is a plethora of literature on the evaluation and selection of textbooks in EFL settings. These studies mainly revolve around the exploitation of textbook evaluation checklists. Kayapinar (2009), for example, evaluated two packages of textbooks, namely Opportunities and New English File. He incorporated 134 instructors' survey results and pointed out that there was not an overall positive attitude towards the aforementioned course book packages among teachers. He also maintained that the course books had to be adapted in a way so that they fulfill learners' needs and interest at nationwide scope. He proposed the evaluation of the materials utilized in the teaching process on a regular basis to be kept renewed.

Also, a study has been conducted by Darali (2007) in regard to the inclusion of pragmatic issues. She analyzed Spectrum series meticulously and mentioned a variety of language functions that were provided in the series. She reported that although the series had covered different language functions, some of them, such as threatening and promising, which are also significant in everyday conversation, not only were in the form of unintended functions, but also they did not appear as frequently as others. 
Another study was carried out by Rastegar (1992) who evaluated and analyzed the dialogs in English textbooks of Guidance and High schools in Iran based on the model by Levinson (1983).

Too, some comparative studies in the textbook evaluation realm have been conducted. Of the most recent ones, one belongs to Vellenga (2004) who made a comparison between ESL and EFL textbooks. She believes that textbooks suffer from dearth of information for learners to acquire pragmatic competence successfully. As she puts it, regarding speech acts in each of the books, there is a focus on explicit mention and metapragmatic description of speech acts such as complaints, apologies, requests, etc.

\section{SIGNIFICANCE OF THE STUDY}

Some language instructors hold widely divergent opinions on controversial issues like textbook adoption. Thus, the results of this study would be of great use to those who are, in one way or another, involved in language learning and teaching processes. Also, the findings of this study would reveal the ILI language teachers' attitudes towards ILI English Series which would be of great significance to material developers and syllabus designers of ILI. Class evaluators and administrators of myriad branches of ILI in Iran would be other groups to benefit from the outcomes of the current study.

\section{OBJECTIVES OF THE STUDY}

It has been a matter of controversy among teachers whether ILI (Iran Language Institute) English Series are appropriate EFL textbooks in terms of satisfying students' needs or not. Accordingly, since there has been no study to explore ILI English Series in the context of Iran, the major thrust of this study is to fully evaluate the Intermediate series of the above-mentioned textbooks. It endeavors to find out whether or not the series can meet the students' needs. Also, this study attempts to see if the teachers are satisfied with the series and its feedback. To this end, this study specifically addresses the following questions:

1. What do EFL instructors think of Intermediate ILI English Series in terms of its suitability in Iran EFL educational setting?

2. How do teachers rank practical considerations, layout and design, activities, skills, language type, and subject and content of the series?

3. Is there any significant difference between the attitudes of male and female teachers towards the series?

\section{METHOD}

\section{A. Textbook}

The textbook which this paper aimed to evaluated was Intermediate ILI English series. This series which consists of three books is one of the six series being taught in ILI, namely Basic, Elementary, Pre Intermediate, Intermediate, High Intermediate, and Advance. Each book encompasses eight units in each of which all four skills have been taken into account. Moreover, such different types of material as Dialogue, Reading, Listening, Grammar (spoken drills), and Vocabulary are included in each unit respectively. The series, as stated in the blurb, follows an eclectic methodology aiming at meeting diverse expectations of adult language learners through variety of supplementary materials to enhance fluency in Listening, Speaking, Reading and Writing. All of the series of books that are being taught in this nationwide institute have been designed and developed by Research and Planning Department of ILI.

\section{B. Procedures for Data Collection}

To conduct the study, the Textbook Evaluation Questionnaire developed by David R. A. Litz (2002) was given out to 80 professional EFL teachers ranging from BA holders to $\mathrm{PhD}$ candidates in different cities and towns of Iran. The reliability of the questionnaire was calculated as 0.86 through a test-retest method with a two-week interval. The instructors who were called for cooperation were experienced enough to express their attitudes with regard to the strengths and weaknesses of the intended series.

\section{Data Analysis}

The obtained data were subjected to statistical analyses pertinent to SPSS 16 for windows. Accordingly, the data of the study were analyzed using descriptive and inferential statistics within the above-mentioned software. Mean and standard deviation were computed in descriptive statistics so as to address the first and second research questions. In this regard, the following Mohammadi scale (2004) was utilized.

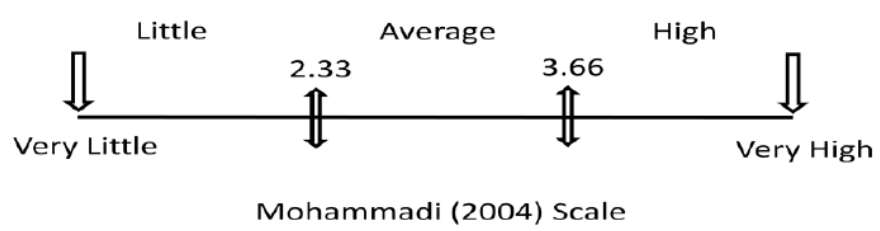


Also, an Independent Samples t-test was carried out to discern if there was any significant difference between male and female responses.

\section{RESULTS AND DisCUSSION}

To address the first research question of this paper descriptive statistics of the data was computed. The results of the analysis are illustrated in the Table 1 below. The table shows the mean and standard deviation obtained for each category. As can be seen, the means of all the subsections of the questionnaire range between 2.8 and 3.45 which, according to Mohammadi (2004) scale, indicate that all teachers have an average level of satisfaction with regard to diverse vantage points included in the questionnaire. The first five items of the questionnaire were sub-sections of 'Practical Considerations' part. These items mainly assessed the points of view of the instructors on the reasonability of textbook's price, its accessibility, publishing qualification, textbook package and authors' views on language and methodology. Table 2 shows in detail the teachers' views on these subsections. The mean scores of the items two and four indicate that teachers are highly satisfied with the ease of accessibility and textbook package since it comes in conjugation with a teacher's manual, a workbook, and a CD. However, a closer look at other mean scores reveals that teachers have neutral attitudes towards the rest of the criteria within 'Practical Considerations'.

TABLE 1

DESCRIPTIVE STATISTICS FOR ALL THE SUBSECTIONS OF THE QUESTIONNAIRE

\begin{tabular}{|l|l|l|l|l|l|}
\hline \multicolumn{2}{l}{ DESCRIPTIVE STATISTICS FOR ALL THE SUBSECTIONS OF THE QUESTIONNAIRE } \\
\hline Sub-Sections & $\mathrm{N}$ & Maximum & Minimum & Mean & Std. Deviation \\
\hline Practical Considerations & 80 & 2.00 & 4.60 & $\mathbf{3 . 2 4 7 5}$ & .62135 \\
\hline Layout and Design & 80 & 2.12 & 5.00 & $\mathbf{3 . 4 5 1 6}$ & .67079 \\
\hline Activities & 80 & 1.00 & 5.00 & $\mathbf{2 . 9 8 2 1}$ & .89095 \\
\hline Skills & 80 & 1.00 & 5.00 & $\mathbf{2 . 8 2 7 5}$ & .84838 \\
\hline Language Type & 80 & 1.67 & 5.00 & $\mathbf{3 . 2 1 0 4}$ & .62796 \\
\hline Subject and Content & 80 & 1.20 & 5.00 & $\mathbf{3 . 1 9 0 0}$ & .84188 \\
\hline Conclusion & 80 & 1.00 & 5.00 & $\mathbf{3 . 0 0 6 2}$ & .94465 \\
\hline
\end{tabular}

TABLE 2

DESCRIPTIVE STATISTICS FOR PRACTICAL CONSIDERATIONS SUB-SECTIONS

\begin{tabular}{|l|l|l|l|l|l|}
\hline Questions & $\mathrm{N}$ & Minimum & Maximum & Mean & Std.Deviation \\
\hline Q1 & 80 & 1 & 5 & 2.49 & 1.125 \\
\hline Q2 & 80 & 1 & 5 & $\mathbf{3 . 9 9}$ & 1.049 \\
\hline Q3 & 80 & 1 & 5 & 2.47 & 1.242 \\
\hline Q4 & 80 & 1 & 5 & $\mathbf{4 . 1 4}$ & 1.064 \\
\hline Q5 & 80 & 1 & 5 & 3.15 & 1.008 \\
\hline
\end{tabular}

'Layout and Design' is the second category of the questionnaire. This category comprised eight items measuring the judges' ideas about the clarity of the materials objectives to the teachers and students, teacher's book's provision of guidance on the utmost advantage of the materials, inclusion of testing suggestions and evaluation quizzes, inclusion of glossary, exercises and review sections, organization of the materials and clarity of the design. The overall mean score and standard deviation (SD) for this category were calculated as 3.45 and 0.67 respectively (see Table 1). The overall mean score of 3.45 implies neither high nor low level of satisfaction in this part. Accordingly, Table 3 shows the ideas of the judges with respect to every individual item. Based on the items six, seven, and nine, one can conclude that nearly most of the instructors were of the opinion that the textbook includes a detailed overview of the function, structures and vocabulary that would be taught in each unit. They were also happy with the inclusion of glossary and appropriateness and clarity of the layout and design. For the rest of the items of this category they have an average level of satisfaction.

TABLE 3

DESCRIPTIVE STATISTICS FOR LAYOUT AND DESIGN SUB-SECTIONS

\begin{tabular}{|l|l|l|l|l|l|}
\hline Questions & $\mathrm{N}$ & Minimum & Maximum & Mean & Std.Deviation \\
\hline Q6 & 80 & 1 & 5 & 3.71 & 1.093 \\
\hline Q7 & 80 & 2 & 5 & 3.66 & .954 \\
\hline Q8 & 80 & 1 & 5 & 3.59 & 1.040 \\
\hline Q9 & 80 & 1 & 5 & 3.82 & 1.028 \\
\hline Q10 & 80 & 1 & 5 & 3.51 & 1.169 \\
\hline Q11 & 80 & 1 & 5 & 2.63 & 1.372 \\
\hline Q12 & 80 & 1 & 5 & 3.30 & 1.354 \\
\hline Q13 & 80 & 1 & 5 & 3.39 & .987 \\
\hline
\end{tabular}

The third category utilized in the questionnaire was that of 'Activities'. Seven items were included in this section (see Table 4). These items were aimed at eliciting the raters' responses with respect to whether or not the activities can be supplemented and modified easily, internalization of newly introduced language can be lubricated through the tasks, creative and independent responses can be promoted through the activities, pair and group work is well accentuated, the grammar points and vocabulary items are introduced in authentic and motivating context. These items also addressed 
the provision of balanced activities regarding free vs. controlled exercises, tasks that focus on both fluent and accurate production, and activities that encourage sufficient communicative and meaningful practice. The overall mean score of this category is 2.98 and its standard deviation is 0.890 (see Table 1) which indicate that teachers were not fully satisfied with regard to the above-mentioned criteria. In much the similar way, none of the items of this category received high degree of satisfaction on the part of the teachers.

TABLE 4

DESCRIPTIVE STATISTICS FOR ACTIVITIES SUB-SECTIONS

\begin{tabular}{|l|l|l|l|l|l|}
\hline Questions & N & Minimum & Maximum & Mean & Std.Deviation \\
\hline Q14 & 80 & 1 & 5 & 2.66 & 1.201 \\
\hline Q15 & 80 & 1 & 5 & 2.85 & 1.284 \\
\hline Q16 & 80 & 1 & 5 & 3.33 & 1.167 \\
\hline Q17 & 80 & 1 & 5 & 2.98 & 1.190 \\
\hline Q18 & 80 & 1 & 5 & 2.97 & 1.201 \\
\hline Q19 & 80 & 1 & 5 & 3.01 & 1.085 \\
\hline Q20 & 80 & 1 & 5 & 3.07 & 1.077 \\
\hline
\end{tabular}

The fourth section of the questionnaire was germane to 'Skills'. As shown in Table 1 the mean score and the standard deviation of this part are 2.82 and 0.84 respectively which in turn show that teachers had the same opinions towards the presentations of skills in the textbooks. This section focuses on tapping the raters' opinions as to whether the textbooks under study take into account those skills that the teachers and the learners need the most, whether these materials have provided an appropriate balance of the four skills, whether they pay attention to the sub-skills, whether they provide occasions for rehearsing natural pronunciation, and finally, whether the series centers on an integration of the four skills (see Table 5). As regards the results obtained for each sub-section of this part (Table 5), the instructors believe that the textbooks are not fully developed in terms of different aspects of skills.

TABLE 5

DESCRIPTIVE STATISTICS FOE SKILLS SUB-SECTIONS

\begin{tabular}{l|l|l|l|l|l|}
\hline Questions & N & Minimum & Maximum & Mean & Std.Deviation \\
\hline Q21 & 80 & 1 & 5 & 3.26 & 1.145 \\
\hline Q22 & 80 & 1 & 5 & 2.76 & 1.183 \\
\hline Q23 & 80 & 1 & 5 & 2.50 & 1.191 \\
\hline Q24 & 80 & 1 & 5 & 2.48 & 1.321 \\
\hline Q25 & 80 & 1 & 5 & 3.14 & .990 \\
\hline
\end{tabular}

The fifth category concerned different aspects of 'Language Type' through six different items. These items focused mainly on evaluating the views of the raters on whether a diverse range of registers and accents have been put forth through the presentation of the language in the textbook, whether the functions included typify those that the learners and the teachers will be likely to use, whether exemplifications and explanations of the grammar points are succinct and simple and whether the progression of the vocabulary and the grammar points is appropriate. Moreover, these items assessed the authenticity of the language used in the textbook and the utilization of the language at the right level for the learners. The overall calculation of mean score and standard deviation for this component is 3.21 and 0.62 respectively (see Table 1) which indicate that teachers have neutral attitudes towards this category altogether. However, the findings in Table 6 revealed that raters agreed that the progression of the grammar points and their presentations through examples and explanations have been practiced to a great extend (see Q28 \& Q29 in Table 6). On the contrary, teachers were not satisfied with the representations of diverse range of registers and accents (see Q31 in Table 6).

TABLE 6

DESCRIPTIVE STATISTICS FOR LANGUAGE TYPE SUB-SECTIONS

\begin{tabular}{|l|l|l|l|l|l|}
\hline Questions & $\mathrm{N}$ & Minimum & Maximum & Mean & Std.Deviation \\
\hline Q26 & 80 & 1 & 5 & 2.83 & 1.290 \\
\hline Q27 & 80 & 1 & 5 & 3.35 & 1.126 \\
\hline Q28 & 80 & 1 & 5 & $\mathbf{3 . 7 2}$ & .900 \\
\hline Q29 & 80 & 1 & 5 & $\mathbf{3 . 8 9}$ & .842 \\
\hline Q30 & 80 & 1 & 5 & 3.18 & 1.016 \\
\hline Q31 & 80 & 1 & 5 & $\mathbf{2 . 3 0}$ & 1.072 \\
\hline
\end{tabular}

'Subject and Content' is the sixth component of the questionnaire which comprises five items. These items measure the following sub- components: whether the text book is pertinent to the students' needs, whether the subject and content of the series are generally realistic, whether the content of the text book is engrossing, challenging and motivating enough, whether the subject and content has fulfilled the requirement of variety, and whether the materials are culturally biased.

As displayed in Table 1 the mean score and standard deviation for this category are 3.19 and 0.84 respectively which maintain that raters are semi-satisfied with this section. In addition, the findings of the sub-sections in Table 7 substantiate the above-mentioned interpretation. 
TABLE7

DESCRIPTIVE STATISTICS FOR SUBJECT AND CONTENT SUB-SECTIONS

\begin{tabular}{|l|l|l|l|l|l|}
\hline Questions & N & Minimum & Maximum & Mean & Std.Deviation \\
\hline Q32 & 80 & 1 & 5 & 3.25 & 1.073 \\
\hline Q33 & 80 & 1 & 5 & 3.21 & 1.122 \\
\hline Q34 & 80 & 1 & 5 & 2.84 & 1.316 \\
\hline Q35 & 80 & 1 & 5 & 3.05 & 1.231 \\
\hline Q36 & 80 & 1 & 5 & 3.60 & .836 \\
\hline
\end{tabular}

The final component of the questionnaire is that of 'Conclusion'. This section manifests teachers' attitudes towards total view of this series through four items. Also, this section mainly assesses (see Table 8) the views of the raters on the appropriateness of the series in terms of language-learning aims such as Listening, Speaking, Reading and Writing skills for all branches of ILI in Iran, the role of the series in raising teachers and students' interest in further English language study, the suitability of the series for small-medium, homogeneous and co-ed classes at ILI, and finally, whether the teachers would choose the textbook again. The overall mean score and standard deviation for this category are 3.00 and 0.94 respectively which shows the average level of satisfaction with this series of books altogether (see Table 1).Moreover, the results obtained for each item of this final component stipulate that raters are of the opinion that this series has not been very well developed so as to meet the needs of the intended audience in the EFL context of Iran.

TABLE 8

DESCRIPTIVE STATISTICS FOR CONCLUSION SUB-SECTIONS
\begin{tabular}{|l|l|l|l|l|l|}
\hline Questions & $\mathrm{N}$ & Minimum & Maximum & Mean & Std.Deviation \\
\hline Q37 & 80 & 1 & 5 & 2.86 & 1.240 \\
\hline Q38 & 80 & 1 & 5 & 3.26 & 1.003 \\
\hline Q39 & 80 & 1 & 5 & 2.88 & 1.195 \\
\hline Q40 & 80 & 1 & 5 & 3.02 & 1.263 \\
\hline
\end{tabular}

In order to answer the second research question, the categories of the questionnaire were ranked based on the judges' level of satisfaction for each component and its corresponding percentage. Table 9 shows the results obtained from the data.

TABLE 9

PERCENTAGE OF SATISFACTION AND RANKING

\begin{tabular}{|l|l|l|l|}
\hline Sub-Category & Mean & Percentage & Rank \\
\hline Layout and Design & $\mathbf{3 . 4 5}$ & $\mathbf{6 9 . 0 3}$ & $\mathbf{1}$ \\
\hline Practical Consideration & 3.24 & 64.95 & 2 \\
\hline Language Type & 3.21 & 64.20 & 3 \\
\hline Subject and Content & 3.19 & 63.80 & 4 \\
\hline Conclusion & 3.00 & 60.12 & 5 \\
\hline Activities & 2.98 & 59.64 & 6 \\
\hline Skills & $\mathbf{2 . 8 2}$ & $\mathbf{5 6 . 5 5}$ & $\mathbf{7}$ \\
\hline
\end{tabular}

As the table clarifies (see mean scores) and as it was mentioned before, all the instructors had an average level of satisfaction towards the intended series based on different criteria included in the questionnaire. The percentage of each mean score has been calculated so as to find out the rank of each component. The raters' levels of satisfaction with regard to the categories are placed in rank order from 1 to 7 . The results in Table 9 imply that among these categories, the one with which the judges are the happiest, is that of "Layout and Design". That is, in comparison with other categories, raters are more satisfied with glossary, section reviews, testing suggestions, layout and design and textbook organization subcategories. 'Practical Considerations' takes the second place which shows that teachers favored reasonability of the price, accessibility of the textbook and textbook package. 'Language Type', 'Subject and Content', 'Conclusion', and 'Activities' are ranked from 3 to 6 respectively. Of those seven categories, 'Skills' is favored the least which in turn indicates that not much heed has been paid to the integration of the four language skills in general and every one skill separately in particular. Moreover, practices of natural pronunciation do not seem to well suit the needs of the learners.

In order to answer the third research question of the study which is germane to the discrepancy between males and females attitudes towards the intended series, Independent Samples t-test was employed. The results of the analysis are shown in the following tables.

TABLE 10.

GROUP STATISTICS FOR PRACTICAL CONSIDERATIONS

\begin{tabular}{|l|l|l|l|l|}
\hline Category & Gender & N & Mean & Std.Deviation \\
\hline \multirow{2}{*}{$\begin{array}{l}\text { Practical } \\
\text { Considerations }\end{array}$} & Male & 40 & 3.20 & .605 \\
\cline { 2 - 5 } & Female & 40 & 3.29 & .640 \\
\hline
\end{tabular}


TABLE 11

INDEPENDENT SAMPLES T-TEST FOR RATERS' ATTITUDES TOWARDS PRACTICAL CONSIDERATIONS

\begin{tabular}{|l|l|l|l|l|l|}
\hline \multirow{2}{*}{ Layout and Design } & \multicolumn{4}{|l|}{ Levene's Test for Equality of Variances } & \multicolumn{1}{l|}{ t-test for Equality of Means } \\
\cline { 2 - 6 } & $\mathrm{F}$ & $\mathrm{Sig}$ & $\mathrm{t}$ & $\mathrm{df}$ & Sig.(2-tailed) \\
\hline Equal Variances assumed & .259 & .612 & -.681 & 78 & .49 \\
\hline Equal Variances not assumed & & & -.681 & 77.76 & .49 \\
\hline
\end{tabular}

The results of Levene's test for equality of variances show that equal variances are assumed (Sig=0.612>0.05). Also, the results of t-test for equality of means indicate that there is not a significant difference between male and female attitudes towards 'Practical Considerations' category.

TABLE 12

GROUP STATISTICS FOR LAYOUT AND DESIGN

\begin{tabular}{|l|l|l|l|l|}
\hline Category & Gender & N & Mean & Std.Deviation \\
\hline \multirow{2}{*}{ Layout and Design } & Male & 40 & 3.46 & .625 \\
\cline { 2 - 5 } & Female & 40 & 3.43 & .720 \\
\hline
\end{tabular}

TABLE 13

INDEPENDENT SAMPLES T-TEST FOR RATERS' ATTITUDES TOWARDS LAYOUT AND DESIGN

\begin{tabular}{|c|c|c|c|c|c|}
\hline \multirow{2}{*}{ Layout and Design } & \multicolumn{2}{|c|}{ Levene's Test for Equality of Variances } & \multicolumn{3}{|c|}{ t-test for Equality of Means } \\
\hline & $\mathrm{F}$ & Sig & $\mathrm{t}$ & df & Sig.(2-tailed) \\
\hline Equal Variances assumed & \multirow[t]{2}{*}{689} & \multirow[t]{2}{*}{.409} & -.228 & 78 & .820 \\
\hline Equal Variances not assumed & & & -.228 & 76.49 & .820 \\
\hline
\end{tabular}

In the same way, the results of Levene's test in Table 13 maintain the equality of variances $(\mathrm{Sig}=0.409>0.05)$. Accordingly, the results of t-test for equality of means clarify that the discrepancy between males and females' responses about 'Layout and Design' category is statistically insignificant ( $\mathrm{Sig}=0.820>0.05)$.

TABLE 14

GROUP STATISTICS FOR ACTIVITIES.

\begin{tabular}{|l|l|l|l|l|}
\hline Category & Gender & N & Mean & Std.Deviation \\
\hline \multirow{2}{*}{ Activities } & Male & 40 & 2.82 & .869 \\
\cline { 2 - 5 } & Female & 40 & 3.14 & .894 \\
\hline
\end{tabular}

TABLE 15

INDEPENDENT SAMPLES T-TEST FOR RATERS' ATTITUDES TOWARDS ACTIVITIES

\begin{tabular}{|c|c|c|c|c|c|}
\hline \multirow{2}{*}{ Activities } & \multicolumn{2}{|c|}{ Levene's Test for Equality of Variances } & \multicolumn{3}{|c|}{ t-test for Equality of Means } \\
\hline & $\mathrm{F}$ & Sig & $\mathrm{t}$ & df & Sig.(2-tailed) \\
\hline Equal Variances assumed & \multirow[t]{2}{*}{.619} & \multirow[t]{2}{*}{.434} & -1.630 & 78 & .107 \\
\hline Equal Variances not assumed & & & -1.630 & 77.93 & .107 \\
\hline
\end{tabular}

As Table 15 shows, the significance value computed for Levene's test is 0.434 which is larger than 0.05 ( $\mathrm{Sig}=$ $0.434>0.05)$. This shows that the variances are assumed equal. Moreover, the results of t-test for equality of means indicate that the difference between male and female judges' responses for 'Activities' category is not significant at the level of $0.05(\mathrm{Sig}=0.107>0.05)$.

TABLE 16

GROUP STATISTICS FOR SKILLS.

\begin{tabular}{|l|l|l|l|l|}
\hline Category & Gender & N & Mean & Std.Deviation \\
\hline \multirow{2}{*}{ Skills } & Male & 40 & 2.70 & .900 \\
\cline { 2 - 5 } & Female & 40 & 2.95 & .783 \\
\hline
\end{tabular}

TABLE 17

INDEPENDENT SAMPLES T-TEST FOR RATERS' ATTITUDES TOWARDS SKILLS

\begin{tabular}{|l|l|l|l|l|l|}
\hline \multirow{2}{*}{ Skills } & \multicolumn{2}{|l|}{ Levene's Test for Equality of Variances } & \multicolumn{1}{l|}{ t-test for Equality of Means } \\
\cline { 2 - 6 } & $\mathrm{F}$ & Sig & $\mathrm{t}$ & df & Sig.(2-tailed) \\
\hline Equal Variances assumed & 1.116 & .294 & -1.351 & 78 \\
\hline Equal Variances not assumed & & -1.351 & 76.51 \\
\hline
\end{tabular}

Table 17 presents the analysis of data pertinent to the component 'Skills'. Based on the significance value computed for Levene's test, the assumption of equality of variances is retained ( $\mathrm{Sig}=0.294>0.05$ ) and the results of t-test for equality of means prove that female and male teachers seem to have the same view towards the skills utilized in the series.

TABLE 18

GROUP STATISTICS FOR LANGUAGE TYPE.

\begin{tabular}{|l|l|l|l|l|}
\hline Category & Gender & N & Mean & Std.Deviation \\
\hline \multirow{2}{*}{ Language type } & Male & 40 & 3.01 & .557 \\
\cline { 2 - 5 } & Female & 40 & 3.40 & .641 \\
\hline
\end{tabular}


TABLE 19

INDEPENDENT SAMPLES T-TEST FOR RATERS' ATTITUDES TOWARDS LANGUAGE TYPE

\begin{tabular}{|c|c|c|c|c|c|}
\hline \multirow{2}{*}{ Language type } & \multicolumn{2}{|c|}{ Levene's Test for Equality of Variances } & \multicolumn{3}{|c|}{ t-test for Equality of Means } \\
\hline & $\mathrm{F}$ & Sig & $\mathrm{t}$ & df & Sig.(2-tailed) \\
\hline Equal Variances assumed & \multirow[t]{2}{*}{1.259} & \multirow[t]{2}{*}{.265} & -2.885 & 78 & .005 \\
\hline Equal Variances not assumed & & & -2.885 & 76.49 & .005 \\
\hline
\end{tabular}

Table 19 illustrates the results of Levene's test for equality of variances and t-test for equality of means. The amount calculated for the former is 0.265 and for the latter is 0.005 which in turn substantiates that the differences between the responses of male and female instructors are statistically significant with respect to 'Language Type' category $(\mathrm{Sig}=0.005<0.05)$.

TABLE 20

GROUP STATISTICS FOR SUBJECT AND CONTENT.

\begin{tabular}{|l|l|l|l|l|}
\hline Category & Gender & N & Mean & Std.Deviation \\
\hline \multirow{2}{*}{ Subject and Content } & Male & 40 & 3.00 & .859 \\
\cline { 2 - 5 } & Female & 40 & 3.37 & .791 \\
\hline
\end{tabular}

TABLE 21

INDEPENDENT SAMPLES T-TEST FOR RATERS' ATTITUDES TOWARDS SUBJECT AND CONTENT

\begin{tabular}{|l|l|l|l|l|}
\hline \multirow{2}{*}{ Subject and Content } & Levene's Test for Equality of Variances & \multicolumn{2}{|l|}{ t-test for Equality of Means } \\
\cline { 2 - 5 } & F Sig & t & Sig.(2-tailed) \\
\hline Equal Variances assumed & .236 & .628 & -2.003 & 78 \\
\cline { 4 - 6 } & & -2.003 & .049 \\
\hline
\end{tabular}

The results of Levene's test in Table 21 maintain the assumption of equal variances (Sig=0.628>0.05). However, the significance value computed for equality of means expresses different views of raters with regard to the 'Subject and Content' category (Sig= $0.049<0.05)$.

TABLE 22

GROUP STATISTICS FOR CONCLUSION.

\begin{tabular}{|l|l|l|l|l|}
\hline Category & Gender & $\mathbf{N}$ & Mean & Std.Deviation \\
\hline \multirow{2}{*}{ Conclusion } & Male & 40 & 2.74 & .918 \\
\cline { 2 - 5 } & Female & 40 & 3.26 & .806 \\
\hline
\end{tabular}

TABLE 23

INDEPENDENT SAMPLES T-TEST FOR RATERS' ATTITUDES TOWARDS CONCLUSION

\begin{tabular}{|l|l|l|l|l|l|}
\hline \multirow{2}{*}{ Conclusion } & Levene's Test for Equality of Variances & \multicolumn{2}{|l|}{ t-test for Equality of Means } \\
\cline { 2 - 6 } & F & Sig & t & df \\
\hline Equal Variances assumed & .000 & .993 & -2.57 & 78 \\
\cline { 4 - 6 } Equal Variances not assumed & & -2.57 & 77.98 \\
\hline
\end{tabular}

The results in Table 23 confirm the equality of variances based on the significance value calculated for Levene's test ( $\mathrm{Sig}=0.993>0.05$ ). In addition, the analysis pertinent to $\mathrm{t}$-test for equality of means proves that the discrepancy between male and female instructors' attitudes towards the 'Conclusion' category is statistically significant $(\mathrm{Sig}=0.01<0.05)$.

\section{CONCLUSION}

Each textbook designed for the purpose of language teaching and learning, regardless of perusing the same goals, encompasses both strengths and weaknesses and the intended series was no exception. This series appears to be effective in such areas as accessibility, function, structure, vocabulary and layout. However, like other textbooks it suffers from some pitfalls and shortcomings. Since the major goal of a textbook is to assist learners in making competent bilinguals in terms of the four language skills, greater up- to- date emphasis should be given to these areas. Also, each textbook should provide the opportunity for the learners to get the hang of the target language culture which is inextricably linked with the language itself.

Having received the average level of satisfaction by the instructors throughout the country in the majority of the parts of the intended series, this study is hoped to assist the material developers and syllabus designers in giving deep thought to the content of the series so as to boost pupils' pragmatic as well as communicative and grammatical competence.

\section{REFERENCES}

[1] Cotazzi, M., \& Jin, L. (1999). Cultural mirrors materials and methods in the EFL classroom. In E. Hinkel (Ed.). Culture in second language teaching and learning. Cambridge: CUP.

[2] Cunningsworth, A. (1995). Choosing your Coursebook. UK: Heinemann English Language Teaching.

[3] Darali, Gh. (2007). Pragmatic dimension in spectrum textbooks. Unpublished master's thesis. Shiraz University, Iran.

[4] Ellis, R. (1997a). SLA research and language teaching. Oxford, UK: Oxford University Press.

[5] Ellis, R. (1997b). The empirical evaluation of language teaching materials.ELT Journal 51(1), 36-42 
[6] Gray, J. (2002). The global coursebook in ELT. In D. Block \& D. Cameron (Eds.), Globalization and language teaching (pp.151-167). New York: Routledge.

[7] Kayapinar, U. (2009). Coursebook evaluation by English teachers. Inonu University Journal of the Faculty of Education, 10(1), 69-78.

[8] Levinson, S.C. (1983). Pragmatics. Cambridge: Cambridge University Press.

[9] Littlejohn, A. (1992). Why are ELT materials the way they are? Unpublished doctoral dissertation, Lancaster University.

[10] Litz, D.R.A. (2000). Textbook Evaluation and ELT Management: A South Korea Case Study. Asian EFL Journal, Retrieved on December 2nd 2013 from http://www.asian-efl-journal.com/Litz_thesis.pdf

[11] Mares, C. (2003). 'Writing a Coursebook'. In B. Tomlinson (Ed), Developing Materials for Language Teaching (PP. 130-140). London: Continuum.

[12] Mohammadi, R. (2004). A practical guide for internal evaluation in Iranian higher educational system. Sanjesh organization, Tehran, Iran.

[13] Mukundan, J. (2007). 'Evaluation of English Language Textbooks, Some Important Issues for Consideration'. Journal of NELTA, Vol 12 No 1\&2: 80-4

[14] O’Neil, R. (1982). 'Why Use Textbooks?'. ELT Journal 36(2), 104-111

[15] Rastegar, Z. (1992). The Analysis of Dialogues in Iranian Guidance and High School Texts in Terms of their pragmatic Functions. Unpublished master's thesis. Shiraz University, Iran.

[16] Sohail, A. (2011). The Procedure of textbook development in Pakistan. Available at: http://www.scribd.com/doc/60627513/Importance-of-Textbook, retrieved on June 15th 2013.

[17] Sheldon, L. (1987). ELT Textbook and Materials: Problems in Evaluation and Development. Oxford: Modern English Publications.

[18] Tomlinson, B. (2008). English Language Learning Materials: A Critical Review. London: Continuum.

[19] Tomlinson, B. (2010). 'Principals of Effective Material Developments'. In N, Harwood (Ed.) (2010). English Language Teaching Materials: Theory and Practice. New York: Cambridge University Press.

[20] Ur, P. (1996). A Course in Language Teaching: Practice and theory. UK: Cambridge University Press.

[21] Vellenga, H. (2004). Learning Pragmatics from ESL \& EFL Textbooks: How Likely? TESL-EJ, 8(2), 1-18.

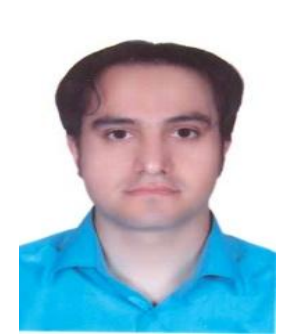

Amir Reza Asiyaban, born in Iran in 1982, is currently a PhD candidate in TEFL in Islamic Azad University of Shiraz. He received his BA and MA degrees from the same university in 2003 and 2009 respectively.

At present, he is teaching preparatory courses for M.A examinations and is working as an English instructor in different institutes and also as a lecturer in the University of Science and Research in Iran, Shiraz. $\mathrm{He}$ has also been an ACADEMIC DIRECTOR, A PLACEMENT TEST ADMINISTRATOR, A TTC TUTOR, and AN OBSERVER in diverse institutes in Shiraz. His main areas of interest are educational psychology, teaching strategies, teacher education and motivation. He has published some articles and a book: - 'Expression via expressions' Shiraz, Eedeh Derakhshan.

- 'L1 and L2 language stores dependency and their connection facilitation through translation'. Iranian EFL Journal, 7(6), 296-308.

- 'Does Translation Contribute to Learners' Free Active Vocabulary?'. Pan-Pacific Association of Applied Linguistics, 16 (1)

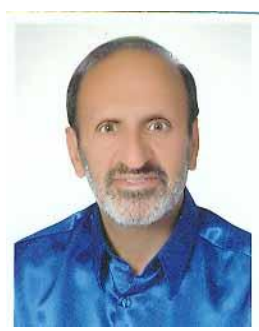

Mostafa Zamanian was born in 1955. He received his PhD degree in the University of UNM, Albuquerque, NM, United States of America in 1984. His major was teaching English.

He has taught at Grambling State University in US and Paul Quinn College in the USA for about 20 years. $\mathrm{He}$ is currently a member of the Academic Staff with the rank of Assistant Professor teaching BA, MA and $\mathrm{PhD}$ courses at Islamic Azad University of Shiraz, Iran. His main areas of interests are Psycholinguistics, Material development, Motivation and Vocabulary. Dr. Mostafa Zamanian is now a program developer for $\mathrm{MA}$ and $\mathrm{PhD}$ courses at the aforementioned University. 